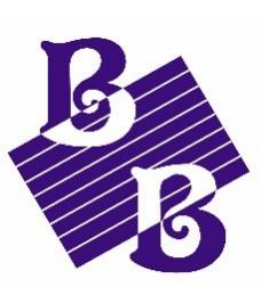

BioBacta
Journal of Bioscience and Applied Research

www.jbaar.org

\title{
The Chemical Constituents and Pharmacological Effects of Nigella sativa
}

- A Review.

\author{
Alyaa Majid* \\ Department of Chemistry, College of Science, University of Thi-Qar, Iraq \\ Corresponding author email: aliaa.s_mschem@sci.utq.edu.iq.
}

DOI: 10.21608/jbaar.2018.151793

\begin{abstract}
This review provides a brief account of the various properties and medicinal usage of the black cumin seed (Nigella sativa). The literature information indicated that seed was extensively used in ancient and recent history as an effective herbal remedy against a wide spectrum of ailments and disease conditions particularly in rural communities in Asia, the Middle East and some other parts of the world. The seed was reported to have numerous biological and pharmacological properties including antioxidant, antibacterial, antifungal, antiparasitic, antiviral, anti-inflammatory, anticancer, antidiabetic, hepatoprotective, immunomodulatory and so many other beneficial medicinal effects. The therapeutic potential of the black cumin seed is mostly related to the presence of some pharmacologically active constituents such as thymoquinone, thymohydroquinone, dithymoquinone, thymol, nigellone and many other phytochemicals. The seed was also found to have a beneficial role in some aspects of poultry products such as improvement of bodyweight performance, feed conversion rate, carcass characteristics, egg production and egg quality when given as a feed additive.
\end{abstract}

Keywords: Black seed, Black cumin, Nigella sativa, Chemical constituents, pharmacology.

\section{INTRODUCTION}

Nigella sativa (N. sativa) (Family

Ranunculaceae) commonly known as black seed, has been used for thousands of years as a spice and food preservative, as well as a protective and curative remedy for several disorders. Traditionally, there is a common Islamic belief that black seed is a universal remedy for all ailments, but cannot prevent ageing or death.
Black seed is also known as the curative black cumin in the Holy Bible and is described as Melanthion by Hippocrates and Dioscorides and as Gith by Pliny. During the last two decades, many studies have been conducted, on the effect of $N$. sativa seed extracts on various body systems in vitro or in vivo ${ }^{(1)}$ Nigella sativa has been widely used from the past to the present for various purposes, including as a painkiller, and anthelmintic, as an 
appetiser, and for carminative, sudorific, digestive, diuretic, emmenagogue, guaiacol, antifebrile, galactagouge and cathartic uses. Nigella sativa is reported to decrease asthenia and depression, and to increase body resistance (2). It has also been highlighted that the active substances of $N$. sativa have antibacterial, antifungal, antidiabetic, immunomodulatory, anti-inflammatory, analgesic, antiviral, antioxidant, anticonvulsant, antihypertensive, anticancer and antihyperlipidemic effects ${ }^{(3,4,5,6)}$. Due to these effects, $N$. sativa seed and oil have been used globally in the treatment of many diseases such as asthma, diarrhoea, dysentery, dyspepsia, fever, icterus, apoplexy, hemorrhoids and cardiovascular, digestive, immune system, liver, respiratory and kidney diseases ${ }^{(7)}$.

Most of the therapeutic properties of this plant are due to the presence of thymoquinone (TQ) which is a major active chemical component of the essential oil. Black seeds are also used in food like flavoring additive in the bread and pickles because it has a very low level of toxicity ${ }^{(8)}$.

\section{Taxonomic Classification}

$\begin{array}{ll}\text { Kingdom } & \text { Plantae } \\ \text { Subkingdom } & \text { Tracheobionta } \\ \text { Superdivision } & \text { Spermatophyta } \\ \text { Phylum } & \text { Magnoliophyta } \\ \text { Class } & \text { Magnoliopsida } \\ \text { Order } & \text { Ranunculales } \\ \text { Family } & \text { Ranunculaceae } \\ \text { Genus } & \text { Nigella } \\ \text { Species } & \text { N. sativa }\end{array}$

\section{Common names}

Black cumin, Fennel Flower, Nutmeg Flower, Black seed, Black Caraway, Roman Coriander, Damascena, Devil in-the-bush, Wild Onion Seed (10).

\section{History of Nigella sativa}

It has been highlighted that $N$. sativa has the richest and most mystical history among all the plants used in medicine. The $N$. sativa oil sample that was discovered in the remnants of Tutankhamun's tomb is indicative of its use since ancient times. It is reported that $N$. sativa seed and oil were used by Hippocrates to strengthen the liver, to solve problems related to the digestive system, to treat snake and scorpion stings, abscesses, skin rashes, infections in the head, and the common cold. It has also been suggested that in later years, Penedius Dioscorides used $N$. sativa oil to relieve headache and toothache, to clear nasal congestion and to destroy enterozoa.

$N$. sativa oil is also stated to have been used for treatment by Ibni Sina to stimulate the metabolism and to relieve asthenia and lethargy (11, 12, 13). Religious statements also highlight the important properties of black cumin. The oil obtained from this plant is known to have been used by Cleopatra, the Queen of Egypt, for health and beauty $(14,15)$. Today, the black cumin seed and oil are assumed to be indispensable source in alternative medicine for the treatment and prevention of various diseases.

\section{Morphology of the plant}

$N$. sativa is an annual flowering plant that grows at $20-90 \mathrm{~cm}$ tall, with finely divided leaves; the flowers are white, yellow, pink, pale blue or pale purple colour, with 5-10 petals. The fruit is a large and inflated capsule consists of 3-7 united follicles, each containing several seeds ${ }^{(14) .}$ Seeds are small dicotyledonous, trigonous, angular, tubercular, black externally and white inside, odour slightly aromatic and taste bitter ${ }^{(16) .}$ 


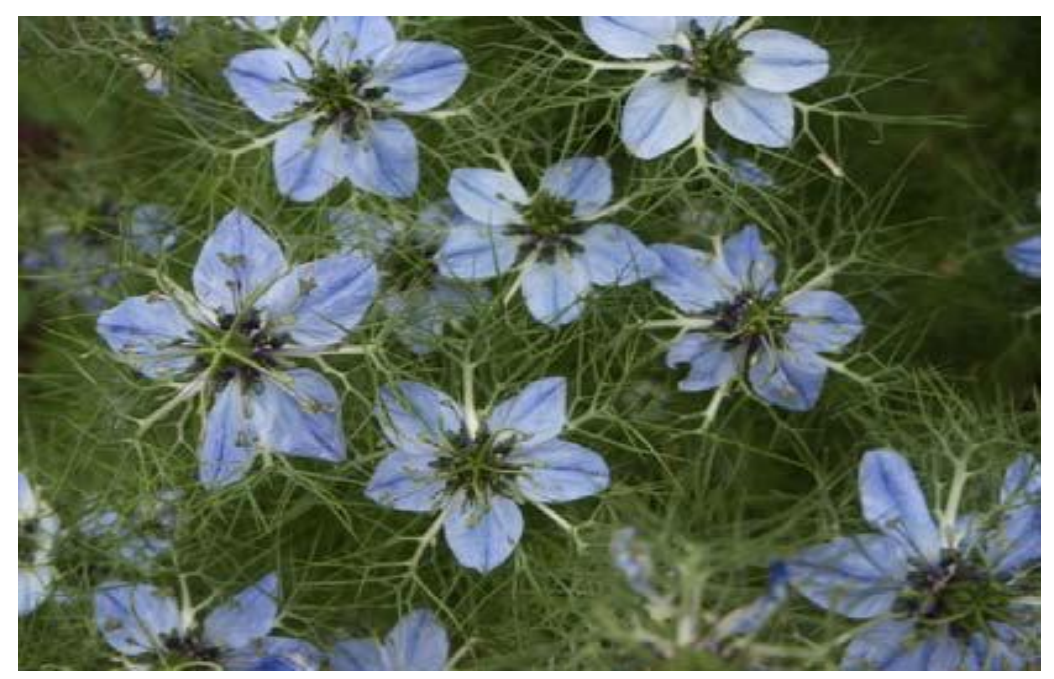

Fig 1: N. sativa flower

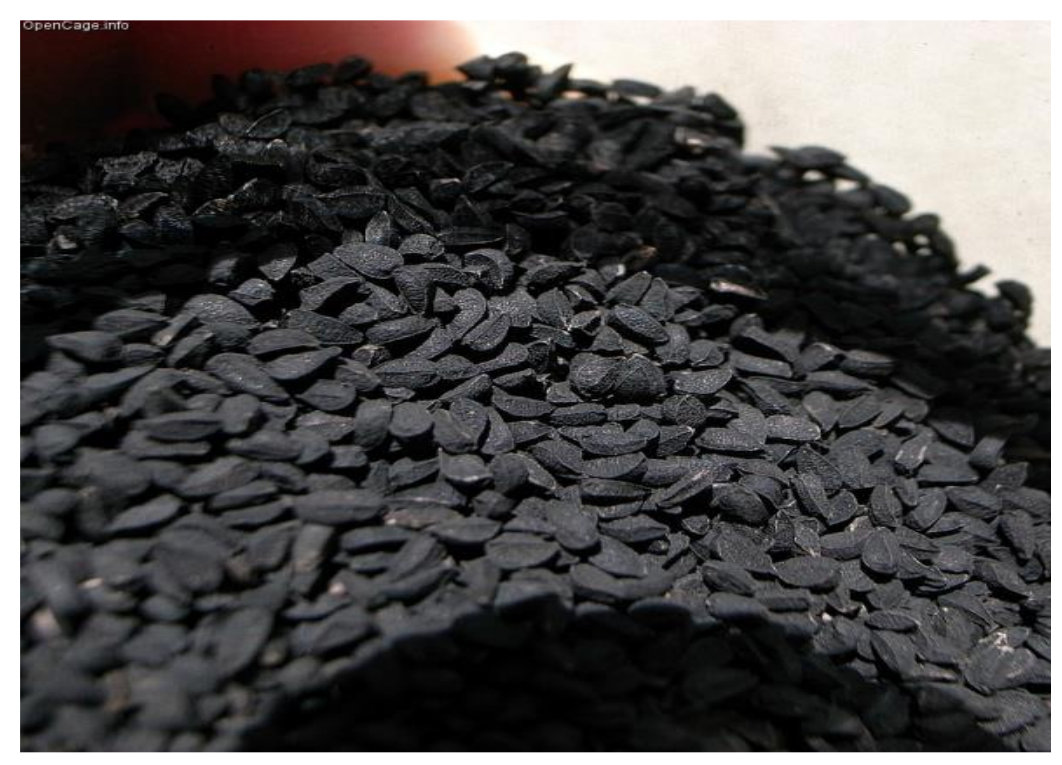

Fig 2: N. sativa seeds

\section{Nigella sativa and it's chemical composition}

The $N$. sativa seed, depending on the region, contains volatile $(0.40 \%-0.45 \%)$ and non-volatile $(32 \%-40 \%)$ oils, protein $(16.00 \%-20.85 \%)$, carbohydrates $(31.0 \%-33.9 \%)$, fibre (5.50-7.94\%), alkaloids, tannins, saponins, minerals such as iron, calcium, potassium, magnesium, zinc and copper $(1.79 \%-3.44 \%)$, vitamin A and C, thiamine, niacin, pyridoxine and folate ${ }^{(17,18,19,20)}$.

Nigella sativa is also rich in unsaturated and essential fatty acids and studies indicate that the volatile oil content ranges from $0.4 \%$ to $2.5 \%(21,22)$. Various other reported chemical components includes nigellone, avenasterol-5-ene, avenasterol7-ene, campesterol, cholesterol, citrostadienol, lophenol, obtusifoliol, stigmastanol, stigmasterol-7ene, $\beta$-amyrin, butyro- spermol, cycloartenol, 24methylene-cycloartanol, taraxerol, tirucallol, 3-O$[\beta$-D-xylopyranosyl $(1 \rightarrow 3)-\alpha-L$ rhamnopyranosyl $(1 \rightarrow 2)$ - $\alpha$-L-arabino-pyranosyl]28-O- $\alpha-\quad$ L-rhamnopyranosyl $(1 \rightarrow 4)-\quad \beta$-Dglucopyranosyl $(1 \rightarrow 6)-\beta$-D- $\quad$ gluco-pyranosyl] hederagenin, volatile oil (0.5-1.6\%), fatty oil (35.6$41.6 \%$ ), oleic acid, esters of unsaturated fatty acids 
with $\mathrm{C} 15$ and higher terpenoids, esters of dehydrostearic and linoleic acid, aliphatic alcohol, melanthin, melanthigenin, bitter principle, tannin, resin, protein, reducing sugar, glycosidal saponin, 3-O- $\quad[\beta-\mathrm{D}$-xylopyranosyl- $(1 \rightarrow 2)-\alpha$-L-rhamnopyranosyl-( $(1 \rightarrow 2)-\beta-\quad$ D-glucopyranosyl]-11methoxy-16, 23-dihydroxy-28-methylolean- 12enoate,stigma-5, 22-dien- 3- $\beta$-D-gluco-pyranoside, cycloart-23-methyl-7, 20, 22- triene-3 $\beta$, 25-diol, nigellidine-4- Osulfite, N. mines $\mathrm{A}_{3}, \mathrm{~A}_{4}, \mathrm{~A}_{5}, \mathrm{C}, \mathrm{N}$. mines $A_{1}, A_{2}, B_{1}$ and $B_{2}{ }^{(23,24) .}$ The most important active constituents are thymoquinone(30\%-48\%), thymohydroquinone, dithymoquinone, pcymene(7\%-15\%), carvacrol (6\%-12\%), 4-terpineol (2\%-7\%), tanethol(1\%-4\%), sesquiterpene longifolene (1\%-8\%) $\alpha$-pinene and thymol etc ${ }^{(24)}$.

Seeds contain two different types of alkaloids; i.e. isoquinoline alkaloids e.g. nigellicimine and nigellicimine- N-oxide, and pyrazol alkaloids or indazole ring bearing alkaloids which include nigellidine and nigellicine. Moreover, N. sativa seeds also contain alpha-hederin, a water-soluble pentacyclic triterpene and saponin, a potential anticancer agent ${ }^{(25) \text {. }}$

\section{Pharmacological activities}

$N$. sativa has been extensively studied for its biological activities and shown to possess a wide spectrum of activities such as a diuretic, antihypertensive, bronchodilator, gastroprotective, hepatoprotective, antidiabetic, anticancer and immunomodulatory, analgesic, antimicrobial, analgesics and anti-inflammatory, spasmolytic, renal protective and antioxidant properties.

\section{Anticancer effects of Nigella sativa}

Cancer is considered to be one of the health concerns that has rapidly become widespread. In 2013, half a million people died of cancer in America, and this rate is even higher in undeveloped countries and 8.2 million people died of cancer worldwide ${ }^{(26) .}$ Some studies showed that Nigella sativa and its active component thymoquinone are claimed to exhibit anticancer activity by causing the death of cancer cells or by preventing genetic changes in normal cells ${ }^{(5)}$. Thymoquinone is considered to have antioxidant, anticarcinogenic and antimutagenic properties. Many studies have shown that $N$. sativa and thymoquinone have antioxidant properties and that they increase the activities of antioxidant enzymes such as superoxide, dismutase, catalase and glutathione peroxidase Because oxidative stress has an effective role in the formation and development of different cancer types and thymoquinone increases the activity of the antioxidant enzymes mentioned above, the positive effects of $N$. sativa against cancer types possibly occur via antioxidant effects ${ }^{(27,28,}$ $29,30)$.

In vitro and in vivo anti-cancer effects of Nigella sativa L. seed extracts was evaluated in one of the studies. In the study, the essential oil and ethyl acetate extracts were showed more cytotoxic effects against the P815 cell line than the butanol extract. Extracts showed a comparable cytotoxic effect against the ICO1 cellline, with IC50 values ranging from 0.2 to $0.26 \%(\mathrm{v} / \mathrm{v})$, but tests on the BSR cell line revealed a high cytotoxic effect of the ethyl 
acetate extract $(\mathrm{IC} 50=0.2 \%)$ compared to the essential oil $(\mathrm{IC} 50=1.2 \%)^{(31)}$.

\section{Antioxidant effects of Nigella sativa}

The beneficial therapeutic, anti-inflammatory and anticancer effects of the black cumin seed have directly been attributed to the potent antioxidant activity of some of its active ingredients particularly thymoquinone ${ }^{(32,33,34)}$. Besides, the seed was also found to contain significant amounts of some other well known potent anti-oxidant elements such as selenium, tocopherols (vitamin E) and trans-retinol (vitamin A) ${ }^{(35,36)}$.

The antioxidant and antiarthritic activity of thymoquinone in Wistar rat by collagen-induced arthritis was evaluated. Oral administration of thymoquinone significantly reduced the levels of pro-inflammatory mediators [IL-1 $\beta$, IL-6, TNF- $\alpha$, IFN- $\gamma$ and PGE (2)] and increased the level of IL$10^{(37) \text {. }}$

\section{Anti-inflammatory effects of Nigella sativa}

The back cumin was reported to have a pronounced anti-inflammatory effect in several inflammatory diseases such as experimental allergic encephalomyelitis (EAE), colitis, and arthritis ${ }^{(38)}$. When animals with EAE received thymoquinone they showed higher glutathione level, absence of lymphocytic perivascular inflammation and absence of disease symptoms, compared with EAE untreated animals. The aqueous extract of the black cumin was also investigated for anti-inflammatory, analgesic and antipyretic activities in animal models. The extract was found to have an antiinflammatory effect demonstrated by its inhibitory effects on Carrageenan - induced paw edema in mice $^{(39)}$.
The extract was also found to produce a significant increase in the hot plate reaction time in mice and thus indicating an analgesic effect. Also, the ethanolic extract of the black cumin was reported to have a significant analgesic effect in mice that were exposed to the acetic acid-induced writhing test ${ }^{(40)}$. Furthermore, the black cumin was found to maintain its inflammatory and analgesic activity even during different phases of germination. The mechanism that mediates the inhibitory effect of the black cumin on inflammatory immune responses is probably attributed to the alteration of trafficking of the inflammatory cells via modulating the expression of chemokines and/or adhesion molecules ${ }^{(41)}$. Even though there are no reported studies on the effect of the black cumin on the chemokines or adhesion molecules, the inhibition of the inflammatory cytokines IL-1, TNF- $\alpha$ and enhancement of the chemokine IL8 by the black cumin might give a positive indication of the anti-inflammatory effect of its active ingredients ${ }^{(12)}$.

\section{Antibacterial effects of Nigella sativa}

Different crude extracts of $N$. sativa exhibited antimicrobial efficacy against different bacterial strains which comprised either gram-negative or gram-positive bacteria. Crude extracts of $N$. sativa showed a potential effect against some of the test organisms. The most effective extracts of $N$. sativa were the crude alkaloid and water extracts. Gramnegative isolates were more susceptible than grampositive ones ${ }^{(42)}$. The authors reported that the black cumin oil extract and the active ingredients thymoquinone and thymohydroquinone isolated from the volatile oil were found to have inhibitory activity against some gram-positive and gramnegative bacteria. Similar results were also reported 
by El-Fatatry (1975) ${ }^{(43)}$ who showed that the extract and the oil exhibited a broad-spectrum activity against many bacterial species. In vitro antibacterial studies have shown that the essential oil had a pronounced antibacterial activity against several organisms including Staphylococcus albus, E. coli, Salmonella typhi and Vibrio cholera even at 1:1000 dilutions. The oil was found to be more effective against gram-positive than gram-negative organisms ${ }^{(43) .}$ Hannan et al. investigated in $2008^{(42) .}$ the antibacterial activity of $N$. sativa against clinical isolates of methicillin-resistant Staphylococcus aureus. All tested strains of methicillin-resistant Staphylococcus aureus in his study were sensitive to ethanolic extract of $N$. sativa at a concentration of $4 \mathrm{mg} /$ disc with a MIC range of $0.2-0.5 \mathrm{mg} / \mathrm{mL}$ (42). In another study, the antibacterial activity of $N$. sativa against and triple therapy in the suppression of Helicobacter Pylori in patients with non-ulcer dyspepsia was determined. $N$. sativa seeds exhibited clinically useful anti-H. pylori activity, comparable to triple therapy ${ }^{(44)}$.

\section{Antifungal effects of Nigella sativa}

The aqueous extract of $N$. sativa seeds exhibits an inhibitory effect against candidiasis in mice ${ }^{(45)}$. Antidermatophyte activity of ether extract of $N$. sativa and thymoquinone was tested against eight species of dermatophytes: four species of Trichophyton rubrum and one each of Trichophyton interdigitale, Trichophyton mentagrophytes, Epidermophyton floccosum and Microsporum canis using the Agar diffusion method. The ether extract of $N$. sativa and thymoquinone show inhibitory activity against fungal strains. The results show the potentiality of $N$. sativa as a source for

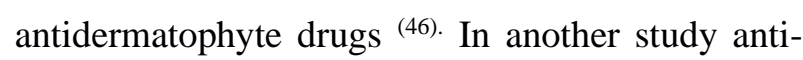
yeast activity of the black cumin seed quinines, dithymoquinone, thymohydroquinone, and thymoquinone was evaluated in vitro against six dairy spoilage yeast species. Thymohydroquinone and thymoquinone possessed significant anti-yeast activity ${ }^{(47) .}$

\section{Antioxytocic effects of Nigella sativa}

$N$. sativa seeds oil inhibit the uterine smooth muscle contraction induced by oxytocin stimulation in rat and guinea pig uterine smooth muscles suggest the anti-oxytocic potential of $N$. sativa seeds oil ${ }^{(48) .}$

\section{Antidiabetic effects of Nigella sativa}

Nigella sativa and its active component thymoquinone have been shown to have positive effects in controlling glucose levels and lipid profiles in diabetics (49). Although the molecular mechanism of thymoquinone on insulin secretion has not been completely clarified, it is reported that thymoquinone causes an increase in glucose use by increasing the serum concentration, and decreasing high levels of serum glucose, and decreasing blood glucose by preventing gluconeogenesis ${ }^{(50)}$.

\section{Antihyperlipidemic and}

\section{Antihypercholesteremic effects of Nigella sativa}

Hypercholesterolemia is reflected by an increase in TG, TC, LDL, HDL and very-low-density lipoprotein (VLDL) levels (51). An increase in the HDL level and a decrease in the LDL level in the circulation have positive effects on reducing the risk of cardiovascular disease ${ }^{(52) .}$ Nigella sativa and its important active component thymoquinone demonstrate an antihypercholesteremic effect by decreasing the level of HMG-CoA reductase enzyme, which is the rate-limiting enzyme in cholesterol synthesis, to cause protective effects on 
dyslipidemia. Moreover, Nigella sativa is reported to display antihyperlipidemic properties by stimulating paraoxonase enzyme (PON1), which functions as an antioxidant, due to its LDL protective property against oxidation and its ability to neutralize radicals including hydrogen peroxide, to increase the activity of arylesterase, the protein indicator of the PON1 enzyme ${ }^{(53)}$.

\section{Cardiovascular effects of Nigella sativa}

The acute effects of diesel exhaust particles on cardiopulmonary parameters in mice and the protective effect of thymoquinone were studied. Diesel exhaust particles were given to mice, intratracheally. Diesel exhaust particles caused systemic inflammation characterized by leucocytosis, increased IL-6 concentrations and reduced systolic blood pressure. Diesel exhaust particles reduced platelet numbers and aggravated in vivo thrombosis in pial arterioles. In vitro, the addition of diesel exhausts particles to untreated blood-induced platelet aggregation. Pretreatment of mice with Thymoquinone prevented diesel exhaust particles induced a decrease of systolic blood pressure and leucocytosis, increased IL-6 concentration. Thymoquinone also averted the decrease in platelet numbers and the prothrombotic events but not platelet aggregation in vitro (54). Another important risk factor for cardiovascular disease is hypertension.

Arabs have used $N$. sativa seed together with honey or garlic for the treatment of hypertension in traditional medicine. It has been suggested that $N$. sativa extract reduces blood pressure in dogs. It has also been claimed that another antihypertensive effect of $N$. sativa oil might result from its diuretic effect (55). An increase in oxidative stress is associated with the pathogenesis of hypertension. Blood pressure increases, depending on the imbalance between the antioxidant defence mechanism and free-radical production. An excessive increase in reactive oxygen products reduces the bioavailability of nitric oxide in endothelium dysfunction and increases the total peripheral resistance ${ }^{(15)}$. In human and animal studies, $N$. sativa and its active component thymoquinone is reported to contribute to a reduction in blood pressure and to reduce hypertension via various mechanisms, such as by antioxidant properties, calcium-channel blockage, and diuretic and hypotensive (soothing heartbeat) functions ${ }^{(55)}$.

\section{Contraceptive and anti-fertility effects of}

\section{Nigella sativa}

The hexane extract of $N$. sativa seeds when orally administered prevented pregnancy in experimental rats at a dose of $2 \mathrm{~g} / \mathrm{kg}$ daily on day's 1-10 postcoitum ${ }^{(56) .}$ In another study, The ethanolic extract of $N$. sativa seeds was found to possess an anti-fertility activity in male rats which might be due to the inherent estrogenic activity of $N$. sativa (57).

\section{Potential Toxicity of Nigella sativa}

Nigella sativa and its oil are reported to have very low toxicity ${ }^{(34)}$. The toxicological properties of thymoquinone were assessed in vitro and in vivo, by treating subjects with thymoquinone at doses between $20 \mathrm{mg} / \mathrm{kg}$ and $500 \mathrm{mg} / \mathrm{kg}{ }^{(58)}$, and death occurred due to other complications when the amount of thymoquinone reached $500 \mathrm{mg} / \mathrm{kg}$. Another study concerning the potential toxicity of $N$. sativa that was conducted on rats, by treating 
them with $2.5 \mathrm{~mL} / \mathrm{kg} /$ day $N$. sativa oil, resulted in no toxicity at the histopathological level(59).

\section{Effects on Animal Production}

In addition to the traditional use of black cumin as a curative agent in popular folk medicine, it was also reported to have some beneficial effects in certain aspects of poultry production (60). For example, incorporation of the black cumin seed in poultry ration at $4.0 \%$ concentration resulted in a significant increase in body weight performance, food intake, feed conversion ratio, dressing percentage and visceral organ weight. It was also reported that supplementation of poultry diet with $1 \%$ black seed has significantly improved body weight gain (BWG) and feed conversion ratio (FCR) in broiler chicks at starter and grower periods (61). Also, dietary supplementation with the black seed was found to improve the carcass quality of broiler chicks ${ }^{(62) .}$ Moreover, the use of the black seed powder as a natural feed additive at a rate of $1.5 \%$ was reported to produce significant beneficial effects on the performance and survivability of broiler chicks (63). The dietary use of powdered black seed was also reported to increase egg production, egg mass and eggshell thickness in laying hens ${ }^{(64) .}$ It is worth mentioning that the European Union has imposed a strict ban on the use of growth-promoting antibiotics and hormones in poultry production due to their potential hazards on human health ${ }^{(65)}$. As a possible effective alternative, the dietary supplementation of the black seed has been recommended by several authors to replace antibiotics and hormones that are routinely used as growth promoters in broiler chicks ${ }^{(66)}$

\section{Conclusions}

This article reviewed Nigella sativa as a promising medicinal plant with a wide range of pharmacological activities which could be utilized in several medical applications because of its effectiveness and safety.

\section{References}

[1] Sultana, S., Asif, HM., Akhtar, N., Iqbal, A., Nazar, H., Rehman, RU. Nigella sativa: monograph. Journal of Pharmacognosy and Phytochemistry 2015; 4:103-106.

[2] Razavi, B. and Hosseinzadeh, H. A review of the effects of Nigella sativa L. and its constituent, thymoquinone, in metabolic syndrome. Journal of Endocrinological Investigation; 37: 1031-1040.

[3] Entok, E., Ustuner, MC., Ozbayer, C., Tekin, N., Akyuz, F., Yangi, B, et al. Anti-inflammatory and antioxidative effects of Nigella sativa L.: 18FDG-PET imaging of inflammation. Molecular Biology Reports 2014; 41: 2827- 2834.

[4] Leong, XF., Rais Mustafa, M., Jaarin K. Nigella sativa and its protective role in oxidative stress and hypertension. Evidence-Based Complementary and Alternative Medicine 2013; 19.

[5] Shafiq, H, Ahmad, A, Masud, T, Kaleem, M. Cardio-protective and anti-cancer therapeutic potential of Nigella sativa. Iranian Journal of Basic Medical Sciences 2014; 17: 967.

[6] Singh, S., Das, S., Singh, G., Schuff, C., de Lampasona, MP., Catalán, CA. Composition, in vitro antioxidant and antimicrobial activities of essential oil and oleoresins obtained from black cumin seeds (Nigella sativa L.). BioMed research international 2014. 
[7] Forouzanfar, F., Bazzaz, BS., Hosseinzadeh, H. Black cumin (Nigella sativa) and its constituent (thymoquinone): a review on antimicrobial effects. Iran J Basic Med Sci 2014;17:929-938.

[8] Al-Ali, A., Alkhawajah, AA., Randhawa, MA., Shaikh, NA. Oral and intraperitoneal LD50 of thymoquinone, an active principle of Nigella sativa, in mice and rats. J Ayub Med Coll Abbottabad 2008; 20: 25-27.

[9] Sharma NK, Ahirwar D, Jhade D, Gupta S. Medicinal and Pharmacological Potential of Nigella sativa: A Review. Ethnobotanical leaflets.2009;11.

[10] Chevallier A. Encyclopedia of Medicinal Plants. New York, NY: DK Publishing. 1996. p. 237. 237.

[11] Botnick, I., Xue, W., Bar, E., Ibdah, M., Schwartz, A., Joel, DM., et al. Distribution of primary and specialized metabolites in Nigella sativa seeds, a spice with vast traditional and historical uses. Molecules 2012; 17: 10159-10177.

[12] Salem, ML. Immunomodulatory and therapeutic properties of the Nigella sativa $\mathrm{L}$. seed. International immunopharmacology 2005; 5: 17491770.

[13] Tembhurne, S., Feroz, S., More, B., Sakarkar, D. A review on therapeutic potential of Nigella sativa (kalonji) seeds. Journal of Medicinal Plants Research 2014; 8: 167-177.

[14] Lord, C., Sekerovic, Z., Carrier, J. Sleep regulation and sex hormones exposure in men and women across adulthood. Pathologie Biologie 2014; 62:302-310.
[15] Paarakh, PM. Nigella sativa Linn. A Comprehensive Review. 2010; 1: 409-429.

[16] Goreja, WG. Black seed nature's miracle remedy. New York. NY 7 Amazing Herbs Press; 2003.

[17] Warrier, PK., Nambiar, VPK., Ramankutty. Indian medicinal plants-a compendium of 500 species. Chennai Orient Longman Pvt Ltd; 2004: 139-142.

[18] Al-Mahasneh, MA., Ababneh, HA., Rababah, T. Some engineering and thermal properties of black cumin (Nigella sativa L.) seeds. International Journal of FoodScience \& Technology 2008; 43: 1047-1052.

[19] Güllü, EB., Gülcan, A. Timokinon: Nigella sativa' nin Biyoaktif Komponenti. Kocatepe Veterinary Journal 2013; 6: 51-61.

[20] Salama, RH. Clinical and Therapeutic Trials of Nigella sativa. TAF PreventiveMedicine Bulletin 2010; 9: 513-522.

[21] Sultan, MT., Butt, MS., Anjum, FM., Jamil, A., Akhtar, S., Nasir, M. Nutritional profile of indigenous cultivar of blackcumin seeds and antioxidant potential of its fixed and essential oil. Pakistan Journal of Botany 2009; 41: 1321-1330.

[22] Hosseinzadeh, H. and Parvardeh S. Anticonvulsant effects of thymoquinone, the major constituent of Nigella sativa seeds, in mice. Phytomedicine 2004; 11: 56- 64.

[23] Ramadan, MF. And Moersel JT. Antiradical performance of some common and nontraditional vegetable oils. Inform 2004; 15: 553-555. 
[24] Nickavar, B., Mojab, F., Javidnia, K., Amoli, MA. Chemic al composition of the fixed and volatile oils of Nigella sativa L. from Iran. Z Naturforsch 2003; 58: 629-631.

[25] Mehta, BK., Pandit, V., Gupta, M. New principles from seeds of Nigella sativa. Nat Prod Res 2009; 23: 138-48.

[26] Al-Jassir, MS. Chemical composition and microflora of black cumin (Nigella sativa L.) seeds growing in Saudi Arabia. Food Chem 1992; 45:239242.

WHO.

(2015).

Cancer.

\section{http://www.who.int/mediacentre/factsheets}

/fs297/en/ (available June, 2016).

[28] Badary, OA., Taha, RA., Gamal El-Din, AM., Abdel-Wahab, MH. Thymoquinone is a potent superoxide anion scavenger. Drug and Chemical Toxicology 2003; 26: 87-98.

[29] Bourgou, S., Ksouri, R., Bellila, A., Skandrani, I., Falleh, H., Marzouk, B. Phenolic composition and biological activities of Tunisian Nigella sativa L. shoots and roots. Comptes Rendus Biologies 2008; 331: 48-55.

[30] Khader, M., Bresgen, N., Eckl, P. Antimutagenic effects of ethanolic extracts from selected Palestinian medicinal plants. Journal of Ethnopharmacology 2010; 127: 319-324.

[31] Randhawa, MA. And Alghamdi, MS. Anticancer activity of Nigella sativa (black seed) a review. The American Journal of Chinese Medicine 2011; 39: 1075-1091.

[32] Mbarek, A., Elabbadi, N., Bensalah, M., Gamouh, A., Aboufatima, Benharref., et al. Antitumor properties of blackseed (Nigella sativa L.) extracts. Brazilian Journal of Medical and Biological Research 2007; 40: 839-847.

[33] Burits, M. and Bucar, F. Antioxidant activity of Nigella sativa essential oil. Phytother. Res. 2000; 14: 323-328.

[34] Mansour, MA., Ginawi, OT., El-Hadiyah, T., El-Khatib, AS., Al-Shabanah, OA., Al-Sawaf, HA. Effects of volatile oil constituents of Nigella sativa on carbon tetrachloride-induced hepatotoxicity in mice: evidence for antioxidant effects of thymoquinone. Res. Commun. Mol. Pathol. Pharmacol 2001; 110:239-251.

[35] Ali, BH, Blunden G. Pharmacological and toxicological properties of Nigella sativa. Phytother. Res 2003; 17:299-305.

[36] Al-Saleh, IA., Billedo, G., El-Doush, Il. Levels of selenium, dl- $\alpha$-tocopherol, dl- $\gamma$-tocopherol, alltrans-retinol, thymoquinone and thymol in different brands of Nigella sativa seeds. J. Food Comp. Analy 2006; 19: 167-175.

[37] Khan, MA. And Afzal, M. Chemical composition of Nigella sativa Linn: Part 2 Recent advances. Inflammopharmacology 2016; 24: 6779.

[38] Umar, S., Zargan, J., Umar, K., Ahmad, S., Katiyar, CK., Khan, HA. Modulation of the oxidative stress and inflammatory cytokine response by thymoquinone in the collagen induced arthritis in Wistar rats. Chem Biol Interact 2012; $197: 40-46$.

[39] Mohamed, A., Shoker, A., Bendjelloul, F., Mare, A., Alzrigh, M., Benghuzzi, H, et al, Improvement of experimental allergic encephalomyelitis (EAE) by thymoquinone; an 
oxidative stress inhibitor. Biomed. Sci. Instrum 2003; 39: 440-445.

[40] Al-Ghamdi, MS. The anti-inflammatory, analgesic and antipyretic activity of Nigella sativa. J. Ethnopharm 2001; 76:45-48.

[41] Bashir, MU. and Qureshi, HJ. Analgesic Effect of Nigella sativa Seeds Extract on Experimentally Induced Pain in Albino Mice. J. Coll. Physicians Surg. Pak 2010; 20 : 464-467.

[42] Hajhashemi, V., Ghannadi, A., Jafarabadi, H. Black cumin seed essential oil as a potent analgesic and anti-inflammatory drug Phytother. Res 2004; 18:195-199.

[43] Hannan, A., Saleem, S., Chaudhary, S., Barka, M., Arshad, MU. Anti-bacterial activity of Nigella sativa against clinicalisolates of methicillin resistant Staphylococcus aureus. J Ayub Med Coll Abbottabad. 2008; 20(3):72-74.

[44] El-Fatatry, HM. Isolation and structure assignment of an anti-microbial principle from the volatile oil of Nigella sativa $\mathrm{L}$ seeds. Pharmazie 1975; 30: 109-111.

[45] Salem, EM., Yar, T., Bamosa, AO., AlQuorain, A., Yasawy, MI., Alsulaiman, RM et al. Comparative study of Nigella sativa and triple therapy in eradication of Helicobacter Pylori in patients with non-ulcer dyspepsia. Saudi J Gastroenterol. 2010; 16:207-214.

[46] Bita, A., Rosu, AF., Calina, D., Rosu, L., Zlatian, O., Dindere, $\mathrm{C}$ et al. An alternative treatment for Candida infections with Nigella sativa extracts. Eur J Hosp Pharm 2012; 19:162.

[47] Aljabre, SH., Randhawa, MA., Akhtar, N., Alakloby, OM., Alqurashi, AM., Aldossary, A.
Antidermatophyte activity of ether extract of Nigella sativa and its active principle, thymoquinone. J Ethnopharm 2005; 101:116-119.

[48] Rogozhin, EA., Oshchepkova, YI., Odintsova, TI., Khadeeva, NV., Veshkurova, ON., Egorov, TA, et al. Novel antifungal defensins from Nigella sativa L. seeds. Plant Physiol Biochem 2011; 49:131-137.

[49] Aqel, M. and Shaheen, R. Effects of the volatile oil of Nigella sativa seeds on the uterine smooth muscle of rat and guinea pig. J Ethnopharm 1996; 52(1):23-26.

[50] Heshmati, J. and Namazi N. Effects of black seed (Nigella sativa) on metabolic parameters in diabetes mellitus: A systematic review. Complementary Therapies in Medicine 2015; 23: 275-282.

[51] Kaatabi, H., Bamosa, AO., Lebda, FM., Al Elq, AH., Al-Sultan, AI. Favorable impact of Nigella sativa seeds on lipid profile in type 2 diabetic patients. Journal of Family and Community Medicine 2012; 19: 155.

[52] Ahmad, A., Husain, A., Mujeeb, M., Khan, S A., Najmi, AK., Siddique, NA., et al. A review on therapeutic potential of Nigella sativa: A miracle herb. Asian Pacific Journal of Tropical Biomedicine 2013; 3: 337-352.

[53] Mani, P. and Rohatgi, A. Niacin therapy, HDL cholesterol, and cardiovascular disease: is the HDL hypothesis defunct? Current Atherosclerosis Reports 2015; 17: 1-9.

[54] Türkoğlu, S., Bulmuş, F G. , Parmaksi, A., Özkan, Y., Gürsu, F. Metabolik sendromlu 
hastalarda paraoksonaz 1 ve arilesteraz aktivite düzeyleri. Firat Tip Dergisi 2008; 13: 110-115.

[55] Nemmar, A., Al-Salam, S., Zia, S., Marzouqi, F., Al-Dhaheri, A., Subramaniyan, D., et al. Contrasting actions of diesel exhaust particles on the pulmonary and cardiovascular systems and the effects of thymoquinone. Br J Pharmacol. 2011; 164:1871-1882.

[56] Keyhanmanesh, R., Gholamnezhad, Z., Boskabady, MH. The relaxant effect of Nigella sativa on smooth muscles, its possible mechanisms and clinical applications. Iranian Journal of Basic Medical Sciences 2014; 17: 939.

[57] Keshri, G., Singh, MM., Lakshmi, V., Kamboj, VP. Post-coital contraceptive efficacy of the seeds of Nigella sativa in rats. Indian J Physiol Pharm 1995; 39:59-62.

[58] Agarwal, C., Narula, A., Vyas, DK., Jacob, D. Effect of seeds of kalaunji on fertility and sialic acid content of the reproductive organs of male rat. Geo Bios 1990; 17:269- 272.

[59] Abukhader, M. The effect of route of administration in thymoquinone toxicity in male and female rats. Indian Journal of Pharmaceutical Sciences 2012; 74: 195.

[60] Yüncü, M., Şahin, M., Bayat, N., İbrahim, S. Çörek otu yağının sıçan karaciğer gelişimine etkisi. Gaziantep Medical Journal 2013; 19: 180-184.

[61] Azeem, T., Zaib Ur-Rahman., Umar, S., Asif, M., Rahman, A. Effect of Nigella sativa on poultry health and production: a review. Sci. Lett 2014; 2:76-82.

[62] Miraghaee, SS., Heidary, B., Almasi, H., Shabani, A., Elahi, M., Nia, MHM. The effects of Nigella sativa powder (black seed) and Echinacea purpurea (L.) Moench extract on performance, some blood biochemical and hematological parameters in broiler chickens. Afr. J. Biotechnol 2011; 10:19249-19254.

[63] Abu- Dieyeh, ZHM. And Abu-Darwish, MS. Effect of feeding powdered black cumin seeds (Nigella sativa L.) on growth performance of 4-8 week-old broilers. J. Anim Vet. Adv 2008; 7: 286290.

[64] Akhtar, MS., Nasir, Z., Abid, AR. Effect of feeding powdered Nigella sativa L. seeds on poultry egg production and their suitability for human consumption. Vet. Arhiv 2003; 73: 181-190.

[65] Casewell, M., Friis, C., Marco, E., McMullin, P. , Phillips The European ban on growth promoting antibiotics and emerging consequences for human and animal health. J. Antimicrob. Chemother 2003; 52:159-161

[66] Attia, YA. And Al-Harthi MA. Nigella seed oil as an alternative for growth promoters for broiler chickens. Europ.Poult.Sci 2015; 79:1 - 15.

[67] Guler, T., Dalklic, B., Erotas, ON., Ciftci, M. The effect of dietary black cumin seed (Nigella sativa $\mathrm{L}$ ) on the performance of broiler. Asian Aus. J. Anim. Sci 2006; 19:425-430. 